\title{
Antisperm Antibodies in Cows as Related to Their Reproductive Health
}

\author{
Z. ZRALÝ, J. ČANDERLE, I. DIBLÍKOVÁ, D. ŠVECOVÁ, J. MAŠKOVÁ, V. KUMMER \\ Veterinary Research Institute, Brno, Czech Republic
}

Received June 29, 2002

Accepted March 25, 2003

Abstract

Zralý Z., J. Čanderle, I. Diblíková, D. Švecová, J. Mašková, V. Kummer: Antisperm Antibodies in Cows as Related to their Reproductive Health. Acta Vet. Brno 2003, 72: 27-32.

Blood sera from 537 cows were examined by ELISA test for antisperm antibodies (ASA). The incidence of ASA in breeding females with impaired reproductive function or reduced reproductive performance was compared to ASA incidence in reproductively normal females. In 420 pluriparous cows, the incidence of positive findings were significantly higher than in 117 primiparous cows $(25.5 \%$ and $12.0 \% ; p<0.01)$. A higher incidence of ASA was observed in cows with two and more inseminations needed to pregnancy. In cows serologically examined and positive to Chlamydia was a significantly higher incidence of ASA than in Chlamydia-negative ones $(33.3 \%$ and $14.7 \% ; p<0.01)$. Significantly lower penetration and velocity $(p<0.01)$ of bulls' spermatozoa through cervical mucus was recorded in heifers serologically positive to ASA after experimental immunisation compared to ASA negative heifers.

Cattle, infertility, insemination, sperm penetration and migration in vitro test, antibody, Chlamydia

The presence of antisperm antibodies in secretions of reproductive organs and blood is often associated with infertility in both humans and laboratory and farm animals (Lukyanenko 1978; Wang and Xie 1990; Nouza et al. 1992; Fichorova and Boulanov 1996; Ulčová-Gallová and Mardešič 1996; Waziri and Fayemi 2000 and others). The bonding of those antibodies to the surface sperm antigens, which are predominantly functional molecules such as receptors and enzymes, can induce enhanced sperm agglutination, modulates acrosome reaction (Bohring et al. 2001), inhibits metabolic processes of sperms and thus decreases their motility and ability to penetrate into oocyte. Last but not least, ASA can take part in limitation of blastocyst development and implantation of embryo (Witkin and David 1998).

ASA are predominantly formed by activation of the mucous immune system of cervix, endometrium and oviduct, where they are active, and consequently enter the blood circulation and transudate back (Ulčová-Gallová and Mardešič 1996). Thus, monitoring of ASA in blood could reflect their presence in reproductive organs.

The objective of the study was to obtain information on the prevalence of ASA in blood sera of cows with different reproductive performance, and to assess interaction of sperms with cervical mucus of heifers serologically positive to ASA after experimental immunisation.

\section{Materials and Methods}

Antisperm antibodies in blood sera of cows

The total of 537 cows (117 primiparous and 420 pluriparous) reared in three different herds were used in the study on antisperm antibodies in blood sera. Cows were divided into six groups based on their history: group I (n $=84$ ) -reproductively healthy cows, which had a normal puerperium, had been artificially inseminated once; group II $(n=114)$ - cows with pathological course of puerperium, inseminated once; group III $(n=85)$ - reproductively

Address for correspondence: MVDr.Zdeněk Zralý, CSc. Veterinary Research Institute Vudcova 70

62132 Brno, Czech Republic
Phone: +42054132124

Fax: +420541321 229

http://www.vfu.cz/acta-vet/actavet.htm 
healthy cows which were pregnant after the first insemination; group IV ( $\mathrm{n}=93$ ) - cows pregnant after the second to third insemination; group V $(n=120)$ - cows pregnant after the fourth to fifth insemination; group VI $(n=41)$ - cows pregnant after more than five inseminations. A part of cows blood sera $(n=340)$ were tested for antibodies against Chlamydia, Gram-negative bacteria that may cause infertility in man and animals (Storz et al. 1976), by a micromethod of complement binding (Sever 1962). The species specific antigen of Chlamydia psittaci (Bioveta, Czech Republic) was used. Antibodies detected in titres 1:20 and higher were assessed as a Chlamydia-positive finding.

Determination of ASA in blood serum was carried out by the ELISA test as described previously (Zralý et al. 1998). Shortly, antigens of bulls' sperms were prepared after repeated centrifugation and washing of sperms and ultrasound treatment. Antigens diluted in binding buffer were bound in wells of microtitre plates for ELISA tests (Gama, Czech Republic). The serially diluted sera were tested and ASA were detected after their reaction with antigen using species specific immunoglobulin labelled with peroxidase (SwAB x Px; Sevac, Czech Republic). After reaction with the substrate, the intensity of the coloured reaction was measured with photometer iEMS Reader MF (Labsystems, Finland) at wave length $492 \mathrm{~nm}$ and evaluated with the computer programme GENESIS. The reaction was considered as positive at absorbance by 2 SD higher than in the negative control sera. Positive reaction at serum dilution 1:40 and higher was considered as serologically positive for ASA.

Interaction of spermatozoa with cervical mucus of heifers

Cervical mucus from cyclic heifers was used in the experiment. Cervical mucus was collected by using a sterile pipette in oestrus (the routine clinical arborisation test to ensure that oestrus was assessed) from two nonimmunised, serologically negative heifers, and two positive to ASA after sperm immunisation (titre 1:640 and $1: 1280$ ). Washed bulls' spermatozoa in a complete Freud's adjuvant (Sigma) were used for immunisation at the initial application, and in the following three immunisations at the interval of 21 days in an incomplete adjuvant. The each immunisation dose of $2 \mathrm{ml}$ was administered intradermal in aliquots of $0.2 \mathrm{ml}\left(1 \mathrm{ml}\right.$ contained $2 \times 10^{9}$ spermatozoa). Interaction of fresh ejaculate spermatozoa from 4 normal healthy bulls (ASA negative with the followings semen characteristics: $70 \%$ of spermatozoa with progressive motility, $80 \%$ normospermy), with cervical mucus of heifers was assessed using the sperm penetration and migration test in vitro (Věžník and Švecová 1992). The distance of sperm shift (penetration in $\mathrm{mm}$ ) was measured as well as sperm velocity (m/s) in a capillary filled with mucus after 30,60 and $90 \mathrm{~min}$. All the examinations were conducted in triplicates of subsequently three times collected ejaculates in monthly intervals. The index of sperm penetration intensity was calculated from the penetration distance and sperm concentration per $1 \mathrm{~mm}^{3}$.

Statistical analysis

Experimental data are presented as the mean S.E.M. Statistical significance of differences between the obtained results was evaluated by $\chi^{2}$-test, the Student's t-test and the test of differences of two relative values using the programme STAT Plus (Matoušková et al. 1993).

\section{Results}

Primiparous

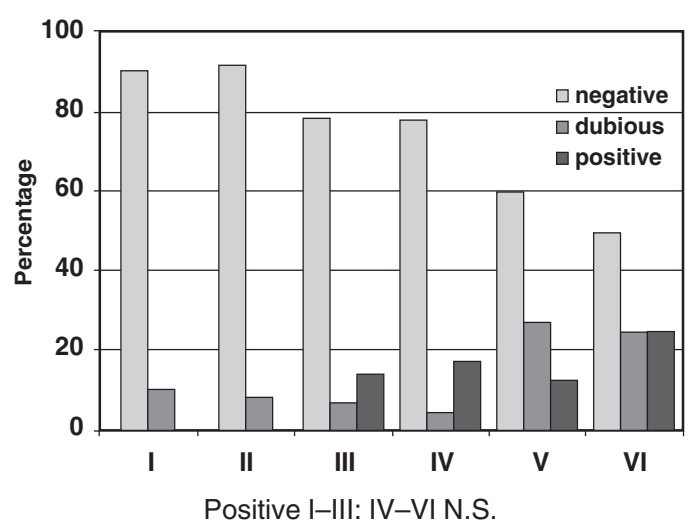

Fig. 1. Incidence of ASA in blood seer of cows

I-physiological puerperium (by one month after insemination)

II - pathological puerperium (by one month after insemination)

III - pregnant after $1^{\text {st }}$ insemination
Of the 537 cows examined, positive findings of ASA (titre 1:40 and higher) were identified in 121 cows, i.e. $22.5 \%$. There were a significantly higher number of positive pluriparous than primiparous animals $(25.5 \%$ and $12.0 \%, p<0.01)$. Antibody titres reached also higher values in the former, up to 1:320, while only in one of the primiparous animals the titre was 1:160 (Fig.1). The course of the puerperium had no effect on the number of animals with a positive response where the cows had been inseminated once. An increased incidence of ASA was recorded in cows that became pregnant after 2 to 3 or more inseminations (groups IV to VI). This was apparent in 172 pluriparous 
cows from the above groups where 69 $(40.1 \%)$ were positive, which is significantly $(p<0.01)$ more compared to $38(15.3 \%)$ positive pluriparous cows from 248 in the groups I to III. From 82 and 35 primiparous cows in the same groups (IV to VI and I to III) was found ASA positive $14.6 \%$, respectively 5.7 $\%(p>0.05)$.

In the group of 340 cows examined for antibodies to Chlamydia, a significantly higher incidence of ASA was observed in a group of 150 cows Chlamydia-positive $(50$ cows, i.e. $33.3 \%$ ) compared to a group of 190 cows Chlamydia-negative of which only 28 cows were ASA positive $(14.7 \% ; p<0.01)$ as shown in Fig. 2.

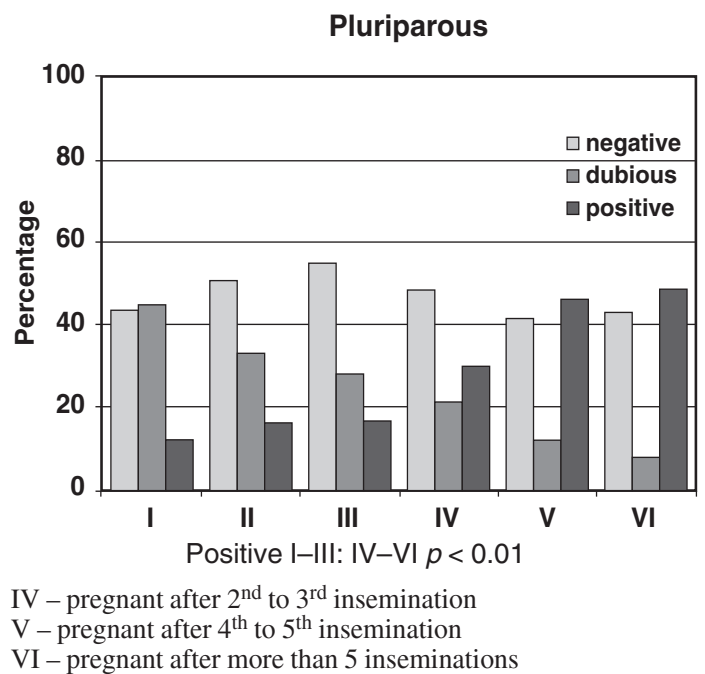

A significantly lower penetration of spermatozoa in cervical mucus was observed in heifers serological to ASA positive after experimental sperm immunisation. After 30 and 60 min the distances penetrated were: $23.1 \pm 2.4$ and $24.5 \pm 3.1 \mathrm{~mm}$, respectively, compared to $33.0 \pm 3.0$ and $38.5 \pm 1.7 \mathrm{~mm}(p<0.05$ and $p<0.01)$ in mucus of serologically negative, control heifers (Fig. 3). In the same time intervals, sperm velocities in mucus of ASA positive heifers, were $12.3 \pm 1.4$ and $6.8 \pm 0.9 \mu \mathrm{m} / \mathrm{s}$, which was significantly lower $(p<0.01)$ compared to $20.0 \pm 0.8$ and $10.7 \pm 0.5 \mu \mathrm{m} / \mathrm{s}$ in mucus of ASA negative heifers. There was a similar tendency towards lower values in the index of sperm penetration in cervical mucus.

Set of chlamydia negative animals

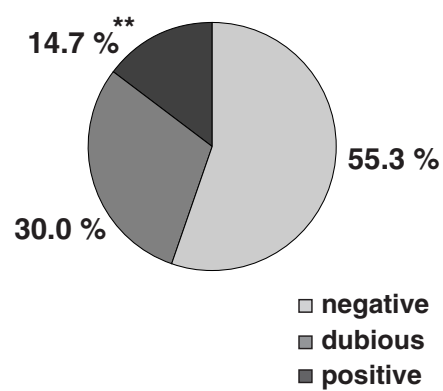

Set of chlamydia positive animals

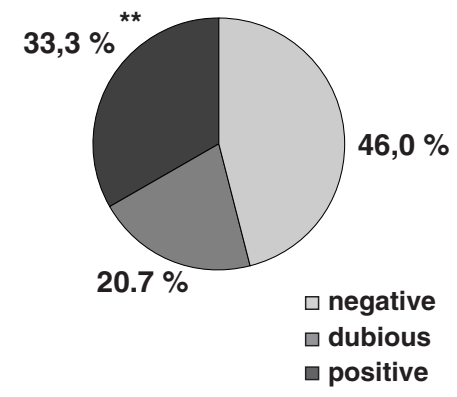

Fig. 2. Incidence of ASA in the groups of chlamydia-negative and chlamydia-positive cows. $* *$ differences between two relative values are statistically highly significant $(T=4.056)$

\section{Discussion}

The presence of ASA in the reproductive organs and blood has been related to infertility in both humans and farm animals by many authors (Lukyanenko 1978; Wang and Xie 1990; Nouza et al. 1992; Fichorova and Boulanov 1996; Ulčová-Gallová and Mardešič 1996; Waziri and Fayemi 2000). Isoimmunisation of females against sperm antigens occurs especially in relation to pathological lesions of the reproductive organs, and followings insemination. The mucous membranes of the reproductive tract produce 


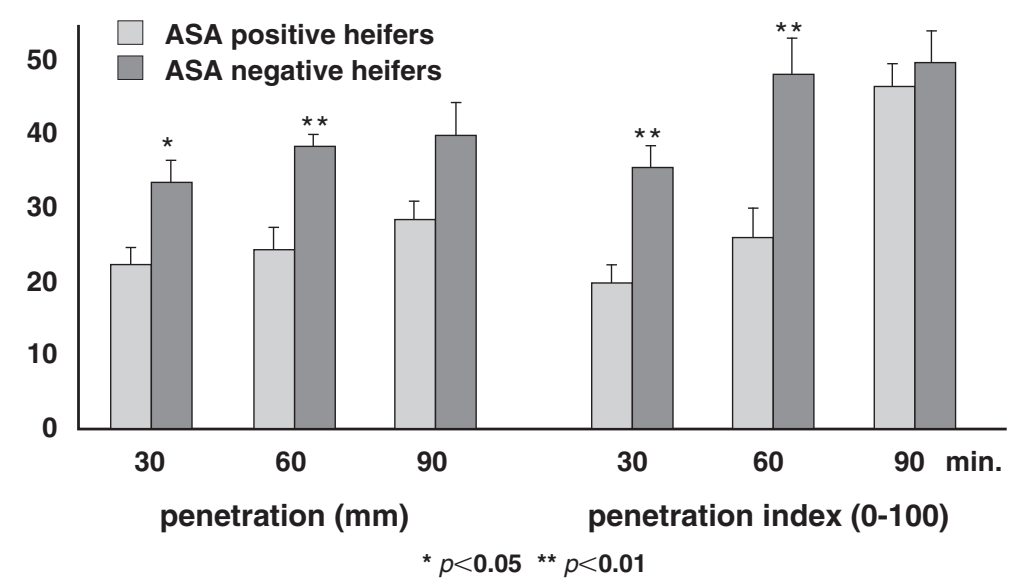

Fig. 3. Penetration of sperm in cervical mucus ASA positive and negative heifers

immunoglobulin isotypes with $\operatorname{IgG}$ being the main only, while in the mucous secretions of other organs IgA is the most common one (Mestecký and Fultz 1999). The frequency of positive ASA findings determined by ELISA in blood sera of cows (22.5\%) corresponds with the findings in goats (15.2\%; W aziri and Fay e mi 2000) or breeding bulls (26.7\% and 35.5\%; Zralý et al. 1998 and 2002). An increased incidence of ASA was observed in breeding cows that, after the last delivery, became pregnant following 2 or more inseminations (31.9\%). Malinovskiy (1976) and Szczubial and Krzyzanowski (1996) obtained similar results using a different method, as well as while assessing spermagglutinine levels in blood sera of cows.

In this study the course of puerperium had no effect on the number of ASA positive cows if they were inseminated only once post partum. No positive findings were detected in primiparous cows with either clinically normal or pathological puerperium (in groups I and II). The pluriparous cows of same groups had certain positive findings, but with no differences in incidence (12.2\% and $16.5 \%$ ). It can be explained by the fact that involution accompanied by tissue destruction and bacterial contamination induced an increase in the number of immunocompetent cells, that in pluriparous cows have already met sperm antigens and dispose of immunological memory for these antigens. Also the endocrine status can be in relation with ASA formation as stated by Wang and Xie (1990) in cows with decreased progesterone concentrations. On the other hand, repeated insemination in cows free of clinical signs of endometrial disease may support the production of ASA and make infertility more serious. In cows free of clinical signs but with higher level of ASA confirmed Luky anenko (1978) by histological examination of endometrium impairment integrity of epithelial surface and increased lymphocyte infiltration. Malinovskiy (1976) stated that between $2^{\text {nd }}$ to $5^{\text {th }}$ insemination ASA titres increased twice to ten times and the frequency of ASA formation and persistence were twice to three times higher in cows with pathological course of puerperium.

Infections of the urogenital tract, especially with Chlamydia and Ureaplasma, also take part in ASA formation and reduced fertility. Elimination of infectious agent by antibiotics renewed fertility in men in case that they had not increased levels of antisperm antibodies (Witkin and Toth 1983). In our experimental group of cows significantly higher incidence of ASA was in animals serologically positive to Chlamydia (33.3\%) than in the negative ones (14.7\%). Chlamydiae are intracellular bacterial pathogens that propagate in epithelial cells and impair their function and integrity of surface structure of organs, i.e. endometrium. 
Regarding the fact that chlamydial infections affect only part of the population, we assume that individually decreased resistance or increased susceptibility play role in ASA formation (Witkin et al. 2000).

Although the relation between ASA and infertility is ambiguous, some proves of this relation exist (Szczubial and Krzyzanowski 1996). Sperm-mucus penetration tests are used for fertility assessment in humans and animals (Matou šek et al. 1988). These tests can provide information that cannot be obtained at routine spermatological examination and should be preferably used at the study of immunological factors in reproduction (EggertKruse et al. 1993). In course of migration of sperms into uterus, an important role plays not only sperm quality but also the characteristics of cervical mucus. Therefore Dev et al. (1996) stress the necessity of cervical mucus quality standardisation for the assessment of bulls' fertility in vitro using a penetration test. Matoušek et al. (1988) obtained low penetration of spermatozoa in mucus without crystallisation (arborisation), it means out of oestrus or in an unsuitable stage of oestrus. Therefore we used cervical mucus, evaluated by the arborisation test, and high quality ejaculates form bulls with excellent fertility to exclude undesired effects. The confirmed significantly lower penetration and velocity of spermatozoa in the mucus of ASA positive heifers suggests a possible transsudation or secretion of these antibodies into cervix. Impairment of sperm movement following antibody binding can be explained by fixation of spermatozoa to glycoprotein fibres of cervical mucus resulting in slower or shaking movement. The obtained results indicate that cervical mucus of ASA positive heifers impairs sperm functions. If ASA titres increase with increasing number of inseminations, and ASA impairs fertility, then this represents "a closed circle".

Our results are in accordance with our previous experience, emphasising the requirement to breed dames only after healing of puerperal diseases and endometrial lesions. Adherence to principles of good practice of insemination can reduce the production of ASA and enhance fertility of cows.

\section{Protilátky proti spermiím v krevním séru krav ve vztahu k jejich reprodukci a zdraví}

Byla vyšetřena krevní séra 537 krav ELISA metodou na př́itomnost protilátek proti spermiím (ASA). Výskyt protilátek u plemenic s poruchami puerperia nebo s nižší reprodukční výkonností byl porovnán se skupinou plemenic bez reprodukčních problémů. U 420 pluriparních krav byla incidence pozitivních nálezů protilátek významně vyšší než u 117 primiparních krav $(25,5 \%$ a $12,0 \% ; p<0,01)$. Průběh puerperia neměl vliv na výskyt ASA pokud byly krávy inseminovány pouze jedenkrát. Avšak krávy s dvěmi a více inseminacemi měly vyšší incidenci protilátek proti spermiím než pouze jedenkrát inseminované, což u pluripar bylo významně rozdílné $(40,1 \%$ a $15,3 \% ; p<0,01)$. Rovněž vyšší nález ASA byl zaznamenán u 150 krav sérologicky pozitivních na chlamydie ve srovnání se 190 negativními $(33,3 \%$ a 14,7 \%; $p<0,01)$. Byla zjištěna signifikantně menší penetrace a rychlost pohybu $(p<0,01)$ spermií býků za 30 a 60 minut v cervikálním hlenu jalovic sérologicky pozitivních na ASA (po experimentální imunizaci) než v hlenu ASA negativních jalovic.

\section{Acknowledgements}

This work was supported by the Czech Ministry of Agriculture (Grant from the National Agency for Agricultural Research in Prague, M 03-99-01).

\section{References}

BOHRING, C, SKRZYPEK, J, KRAUSE, W 2001: Influence of antisperm antibodies on the acrosome reaction as determined by flow cytometry. Steril Fertil 76: 275-280

DEV, S, PANGAWKAR, GR, SHARMA, RK 1996: In vitro sperm mucus penetration test to evaluate bull fertility. Ind J Anim Sci 66: 1021-1022 
EGGERT-KRUSE, W, SCHWALBACH, B, ROHR, G, KLINGA, K, TILGEN, W, RUNNEBAUM, B 1993: Evaluation of polyacrylamide-gel as substitute for human cervical-mucus in the sperm penetration test. Fertil Steril 60: $540-549$

FICHOROVA, RN, BOULANOV, ID 1996: Anti-seminal plasma antibodies associated with infertility. 1. Serum antibodies against normozoospermic seminal plasma in patients with unexplained infertility. Am J Reprod Immunol 36: 198-203

LUKYANENKO, VM 1978: Ob immunobiologičeskom sostojanii besplodnych korov. Veterinarija (Moskva) 10: $72-73$

MALINOVSKIY, IF 1976: Oplodotvorjajemost korov v zavisimosti ot titra spermoantitel v syvorotke krovi. Dostizh Vet Nauki Pered Opyta Zhivotnovod 2: 77-78

MATOUŠKOVÁ, O, CHALUPA, J, CÍGLER, M, HRUŠKA, K 1993: Statistický a grafický systém STAT Plus verze 1.10 . Výzkumný ústav veterinárního lékařství, Brno, 168 p.

MATOUŠEK, J, Ř́HA, J, SRŠEŇ, V, VESELSKY, L, LOUDA, F 1988: Penetration of cervical mucus and other body fluids by bull sperm in capillary tubes. Anim Reprod Sci 18: 161-166

MESTECKY, J, FULTZ, P N 1999: Mucosal immune system of the human genital tract. J Infect Diseases 179 (Suppl 3): S470-474

NOUZA, K, KINSKY, ., DIMITROV, D 1992: Immunology and immunopathology of reproduction. Folia Biol (Praha) 38: 170-194

SEVER, JL 1962: Application of microtechnique to viral serological investigations. J Immunol 88: 320-328

STORZ, J, CARROLL, EJ, STEPHENSON, EH, BALL, L, EUGSTER, AK 1976: Urogenital infection and seminal excretion after inoculation of bulls and rams with chlamydiae. Am J Veter Res 37: 517-520

SZCZUBIAL, M, KRZYZANOWSKI, J 1996: Miano spermaglutynin w surowicy krwi krów wielokrotnie nieskutecznie inseminowanych. Medycyna Wet 52: 384-385

ULČOVÁ-GALLOVÁ,Z, MARDEŠIC, T 1996: Does in vitro fertilization (IVF) influence the levels of sperm and zona pellucida (ZP) antibodies in infertile women? Am J Reprod Immunol 36: 216-219

VĚŽNÍK, Z, ŠVECOVÁ, D 1992: Soubor metod k hodnocení pohlavních funkcí býků. Ústav veterinární osvěty, Pardubice, $184 \mathrm{p}$

WANG, G, XIE, CH 1990: The relationship between antisperm antibodies and progesterone in the serum of infertile dairy cows. Acta Vet Zootech Sinica 21: 26-30

WAZIRI, MA, FAYEMI, OE 2000: Seroprevalence of sperm antibodies in goats. Veterinarski Archiv 70: 95-102

WITKIN, SS, TOTH, AT 1983: Relationship between genital tract infections, sperm antibodies in seminal fluid, and fertility. Fertil Steril 40: 805-808

WITKIN, SS, DAVID, SS 1998: Effect of sperm antibodies on pregnancy outcome in a subfertile population. Am J Obstet Gynecol 158: 59-62

WITKIN, SS, LINHARES, I, GIRALDO, P, JEREMIAS, J 2000: Individual immunity and susceptibility to female genital tract infection. Am J Obstet Gynecol 183: 252-256

ZRALÝ, Z, BENDOVÁ, J, ŠIŠÁK, M, DIBLÍKOVÁ, I, ŠVECOVÁ, D, ZAJÍCOVÁ, A, VĚŽNÍK, Z 1998: Occurrence of antibodies to the sperms in blood sera of bulls and boars. Vet Med - Czech 43: 137-144

ZRALÝ, Z, BENDOVÁ, J, DIBLÍKOVÁ, I, ŠVECOVÁ, D, KUMMER, V, MAŠKOVÁ, J, VĚŽNÍK, Z 2002 : Antisperm antibodies in blood sera of bulls and correlation with age, breed and ejaculate quality. Acta Vet Brno 71: $303-308$ 